\title{
Journal of Pharmacognosy and Phytochemistry
}

\author{
Available online at www.phytojournal.com
}

E-ISSN: 2278-4136

P-ISSN: 2349-8234

JPP 2018; 7(6): 01-04

Received: 01-09-2018

Accepted: 02-10-2018

Barbara M Humtsoe

Department of Agronomy,

Sam Higginbottom University of

Agriculture, Technology and

Sciences, Allahabad,

Uttar Pradesh, India

\section{Joy Dawson}

Department of Agronomy,

Sam Higginbottom University of

Agriculture, Technology and

Sciences, Allahabad,

Uttar Pradesh, India

\section{Praveena Rajana}

Department of Agronomy,

Sam Higginbottom University of

Agriculture, Technology and

Sciences, Allahabad,

Uttar Pradesh, India

\section{Effect of nitrogen, boron and zinc as basal and foliar application on growth and yield of maize (Zea mays L.)}

\author{
Barbara M Humtsoe, Joy Dawson and Praveena Rajana
}

\begin{abstract}
The experiment consisted of two levels of Nitrogen at 120 and $150 \mathrm{~kg} \mathrm{ha}^{-1}$, basal application of Boron (5 $\left.\mathrm{kg} \mathrm{ha}^{-1}\right)$ and Zinc $\left(25 \mathrm{~kg} \mathrm{ha}^{-1}\right)$, without and with combination of foliar application of Boron $(0.3 \%$ at 15 DAS) and Zinc ( $0.25 \%$ at 30 DAS). There were 12 treatments which were replicated thrice and laid out in a Randomized Block Design. Higher plant height, maximum plant dry weight, crop growth rate, more number of cobs plant ${ }^{-1}$, more number of grains $\mathrm{cob}^{-1}$, test weight and grain yield was recorded with (Treatment 12) $\mathrm{N}$ at $150 \mathrm{~kg} \mathrm{ha}^{-1}$ (along with P \& K each at $75 \& 60 \mathrm{~kg} \mathrm{ha}^{-1}$ ) in combination with Zinc at $25 \mathrm{~kg} \mathrm{ha}^{-1}$ as basal and Boron at $0.3 \%$ as foliar spray. This treatment also recorded highest gross return, net return and benefit cost ratio.
\end{abstract}

Keywords: Nitrogen, boron, zinc, basal, foliar application, growth, yield, maize, Zea mays L.

\section{Introduction}

Maize (Zea mays L.) is the most important crop by volume among all cereal grain crops, such as wheat and rice, which are widely grown throughout the world in subtropical and temperate agro-climatic regions (Fageria et al., 1991; Martin et al., 1976) ${ }^{[7,18]}$. It is cultivated in all the soil types (except in sandy soil) and agro-climatic conditions. Being a photoinsensitive crop, maize has been adopted in different seasons and in different regions, with crop duration ranging from <90-130 days. The diversified usages of maize grain make the crop very special for different stakeholders. Maize is the third most important crop after rice and wheat in India, engaging directly more than 12 million maize growers and contributing two per cent to the total value of output from all the agricultural crops in the country. Maize is grown in a wide range of production environments, ranging from the temperate hill zones to the semi-arid desert margins and in all three seasons- Kharif, Rabi and Zaid. The last few years have seen dramatic changes in the production and productivity of maize, as it registered highest growth among all other food crops in the past five years. More than three-fourth of area under production of maize is contributed by Andhra Pradesh, Bihar, Karnataka, Madhya Pradesh, Maharashtra, Rajasthan, Uttar Pradesh and Tamil Nadu.

Nitrogen $(\mathrm{N})$ is a vital plant nutrient and a major determiningfactor required for maize production. It is very essential for plant growth and makes up 1-4\% of dry matter of the plants. Nitrogen is a component of protein and nucleic acids and when $\mathrm{N}$ is sub-optimal, growth is reduced. Its availability in sufficient quantity throughout the growing season is essential for optimum maize growth. It is also a characteristic constituent element of proteins and also an integral component of many other compounds essential for plant growth processes including chlorophyll and many enzymes. It also mediates the utilization of phosphorus, potassium, and other elements in plants. Optimal amount of these elements in the soil cannot be utilized efficiently if nitrogen is deficient in plants. Therefore, nitrogen deficiency or excess can result in reducing maize yields.

Maize has been previously considered to have a relatively low boron (B) requirement compared with other cereals (Marten and Westermann 1991) ${ }^{[17]}$. Deficiency of B in field grown maize was first observed in the 1960s in the United States (Shorrocks and Blaza 1973) [28], and yield increases of more than $10 \%$ were observed in response to B application (Woodruff et al., 1987) ${ }^{[32]}$. In B-deficient maize, poor grain-setting can resultin barren cobs, and this was attributed by Vaughan (1977) ${ }^{[31]}$ to the silks being non-receptive.

Maize is a crop sensitive to zinc supply as indicated by its high content in grain, as compared to other micronutrients (Lošák et al. 2011, Maňásek et al. 2013) ${ }^{[14,16]}$. Zinc has several important functions in plants, including major roles in enzyme reactions, photosynthesis, DNA transcription and auxin activity.

\section{Barbara M Humtso}

Department of Agronomy,

Sam Higginbottom University of

Agriculture, Technology and

Sciences, Allahabad,

Uttar Pradesh, India 
Deficiency of $\mathrm{Zn}$ in soil causes deficiency in crops and altogether this has become a problem all over the world with acute zinc deficiency ranges in arid to semi-arid regions of the world (Rashid and Ryan, 2004) ${ }^{[22]}$.

Moreover, the proper method of nutrient application can be another approach for better uptake and utilization of $\mathrm{Zn}$. Amongst the different methods; the foliar spray of micronutrients is efficient for enhancement of crop productivity (Savithri et al., 1999) ${ }^{[24]}$. This way of nutrient application is an easy and simple method for improvement of plant nutritional condition, as stated for maize and wheat (Erenoglu et al., 2002; Grzebisz et al., 2008) ${ }^{[6,9]}$. Reasons for effectiveness of foliar spray are simple due to its direct application to the leaves (Baloch et al., 2008) ${ }^{[3]}$.

Thus, the objective of this study was to study the effect of Nitrogen, Boron and Zinc on growth and yield of Maize and to evaluate the economics of different treatment combinations.

\section{Materials and methods}

An experiment was conducted during the Kharif season of 2017 in Maize crop at Crop Research Farm, Department of
Agronomy, Naini Agricultural Institute, SHUATS, Allahabad, U.P. The experiment consisted of two nitrogen levels, i.e., 120 and $150 \mathrm{~kg} \mathrm{~N} / \mathrm{ha}$ through urea, along with uniform dose of Phosphorus (75 $\mathrm{kgha}^{1}$ ) through DAP (di-ammonium phosphate) and Potash $\left(60 \mathrm{kgha}^{-1}\right)$ through muriate of potash, basal application of Boron $\left(5 \mathrm{~kg} \mathrm{ha}^{-1}\right)$ and Zinc $\left(25 \mathrm{~kg} \mathrm{ha}^{-1}\right)$, foliar application of Boron $(0.3 \%$ at 15 DAS) and Zinc $(0.25 \%$ at 30 DAS) laid out in a Randomized Block Design with twelve treatment combinations replicated thrice. The soil of the experimental field was sandy loam in texture with $\mathrm{p}^{\mathrm{H}}$ 7.6, low in organic carbon $0.230 \%$, available $\mathrm{P} 9.4 \mathrm{~kg} / \mathrm{ha}$ and available K $187.5 \mathrm{~kg} / \mathrm{ha}$. Maize variety "P 3401"was sown on $18^{\text {th }}$ of July2017. Half of nitrogen as per treatment and full dose of phosphorus, potassium and remaining half dose of Nitrogen was top dressed into equal splits at knee high stage (30 DAS) and tasseling stage (60 DAS). The crop received three irrigations. All the growth and yield attributes were recorded using standard procedure. The crop growth rate (CGR) and relative growth rate (RGR) was calculated using the standard procedure and formulae.

Table 1: Effect of Nitrogen, Boron and Zinc as basal and foliar application on growth and yield of Maize

\begin{tabular}{|c|c|c|c|c|c|c|c|}
\hline \multicolumn{8}{|c|}{ Growth and Yield attributes } \\
\hline \multicolumn{2}{|r|}{ Treatment } & $\begin{array}{c}\text { Dry weight } \\
(\mathrm{g})\end{array}$ & $\begin{array}{c}\text { No. of cobs } \\
\text { plant }^{-1}\end{array}$ & $\begin{array}{c}\text { No. of } \\
\text { grains cob-1 }\end{array}$ & $\begin{array}{l}\text { Test weight } \\
(\text { g) }\end{array}$ & $\begin{array}{c}\text { Grain yield } \\
(\mathrm{t} \mathrm{ha-1})\end{array}$ & $\begin{array}{c}\text { B:C } \\
\text { Ratio }\end{array}$ \\
\hline $\mathrm{T}_{1}$ & NPK at $120,75 \& 60 \mathrm{~kg} \mathrm{ha}^{-1}$ (control) & 56.33 & 5 & 263.83 & 19.38 & 4.43 & 0.88 \\
\hline $\mathrm{T}_{2}$ & NPK at $150,75 \& 60 \mathrm{~kg} \mathrm{ha}^{-1}$ & 52.67 & 5 & 263.33 & 18.66 & 4.23 & 0.78 \\
\hline $\mathrm{T}_{3}$ & NPK at $120,75 \& 60 \mathrm{~kg} \mathrm{ha}^{-1}+$ Boron $5 \mathrm{~kg} \mathrm{ha}^{-1}$ (Basal) & 45.33 & 5.33 & 273.17 & 20.19 & 5.10 & 1.05 \\
\hline $\mathrm{T}_{4}$ & NPK at $150,75 \& 60 \mathrm{~kg} \mathrm{ha}^{-1}+$ Boron $5 \mathrm{~kg} \mathrm{ha}^{-1}$ (Basal) & 45.33 & 5.33 & 271.83 & 18.83 & 4.67 & 0.86 \\
\hline $\mathrm{T}_{5}$ & NPK at $120,75 \& 60 \mathrm{~kg} \mathrm{ha}^{-1}+$ Boron $0.3 \%$ (Foliar) & 72 & 5.33 & 276.5 & 21.51 & 5.50 & 1.29 \\
\hline $\mathrm{T}_{6}$ & NPK at $150,75 \& 60 \mathrm{~kg} \mathrm{ha}^{-1}+$ Boron $0.3 \%$ (Foliar) & 80 & 5.67 & 276.67 & 21.11 & 5.73 & 1.37 \\
\hline $\mathrm{T}_{7}$ & NPK at $120,75 \& 60 \mathrm{~kg} \mathrm{ha}^{-1}+$ Zinc $25 \mathrm{~kg} \mathrm{ha}^{-1}$ (Basal) & 72 & 5.33 & 271 & 21.04 & 5.3 & 1.19 \\
\hline $\mathrm{T}_{8}$ & NPK at $150,75 \& 60 \mathrm{~kg} \mathrm{ha}^{-1}+$ Zinc $25 \mathrm{~kg} \mathrm{ha}^{-1}$ (Basal) & 79.67 & 6.33 & 274.33 & 20.93 & 6.27 & 1.57 \\
\hline $\mathrm{T}_{9}$ & NPK at $120,75 \& 60 \mathrm{~kg} \mathrm{ha}^{-1}+$ Zinc $0.25 \%$ (Foliar) & 57 & 5.33 & 294.67 & 21.41 & 5.83 & 1.45 \\
\hline $\mathrm{T}_{10}$ & NPK at $150,75 \& 60 \mathrm{~kg} \mathrm{ha}^{-1}+$ Zinc $0.25 \%$ (Foliar) & 53.67 & 5.33 & 293.33 & 21.86 & 5.93 & 1.5 \\
\hline $\mathrm{T}_{11}$ & $\begin{aligned} \text { NPK at } 120,75 & \& 60 \mathrm{~kg} \mathrm{ha}^{-1}+\text { Boron } 5 \mathrm{~kg} \mathrm{ha}^{-1} \text { (Basal) } \\
& + \text { Zinc } 0.25 \% \text { (Foliar) }\end{aligned}$ & 76 & 6.33 & 300.33 & 22.13 & 7.27 & 1.91 \\
\hline $\mathrm{T}_{12}$ & $\begin{array}{c}\text { NPK at } 150,75 \& 60 \mathrm{~kg} \mathrm{ha}^{-1}+\text { Zinc } 25 \mathrm{~kg} \mathrm{ha}^{-1} \text { (Basal) } \\
+ \text { Boron } 0.3 \% \text { (Foliar) }\end{array}$ & 83.67 & 6.67 & 304 & 22.39 & 7.90 & 2.17 \\
\hline & F- test & $\mathrm{S}$ & $\mathrm{S}$ & $\mathrm{S}$ & $\mathrm{S}$ & $\mathrm{S}$ & \\
\hline & S. Ed. $( \pm)$ & 10.66 & 0.44 & 12.02 & 0.97 & 0.74 & \\
\hline & C. D. $(P=0.05)$ & 22.11 & 0.92 & 24.93 & 2.02 & 1.52 & \\
\hline
\end{tabular}

\section{Results and discussion}

\section{Growth parameters}

The growth indices of Maize indicated that the application of Nitrogen at $150 \mathrm{~kg} \mathrm{ha}^{-1}$ along with Zinc at $25 \mathrm{~kg} \mathrm{ha}^{-1}$ as basal and foliar application of Boron at $0.3 \%$ produced significantly higher growth attributing characters, i.e. plant height (190.6 $\mathrm{cm})$, dry weight $(83.67 \mathrm{~g})$ and crop growth rate $\left(4.29 \mathrm{~g} \mathrm{~m}^{-2}\right.$ day $\left.^{-1}\right)$. The results of the present investigation are in close conformity with Hassan Amin (2011) ${ }^{[1]}$ who observed that the increase in plant height with nitrogen sources can be attributed to the fact that nitrogen promotes plant growth, increases the number and length of the internodes which results in progressive increase in plant height. Similar results were reported by Sharma (1973) [27], Turkhede and Rajendra (1978) [30], Koul (1997) [12], Saigusa et al. (1999) ${ }^{[23]}$ and Gasim (2001) ${ }^{[8]}$. Arya and Singh (2001) ${ }^{[2]}$ recorded that the dry-matter accumulation was also increased significantly with increasing levels of Zinc up to $30 \mathrm{~kg} \mathrm{ZnSO}_{4}$. Tahir et al., (2012) ${ }^{[29]}$ observed that increasing concentration of boron significantly affected the growth parameter like plant height, leaf area, stem diameter and CGR. Findings of present research are well in agreement with that of Ceyhan et al. (2007) and Mazher et al. (2006) ${ }^{[19]}$.

However, the significant value in relative growth rate was observed in application of Nitrogen @ $150 \mathrm{~kg} \mathrm{ha}^{-1}$ along with foliar spray of Zinc @ 0.25\%. Shanti et al., (1997) [11] observed that the adequate supply of $\mathrm{N}$ might have helped the maize plants to increase their growth, which in turn put forth more photosynthetic surface and leaf area index (LAI), thus contributing more dry matter which ultimately increased relative growth rate.

\section{Yield attributes and Yield}

Nitrogen at $150 \mathrm{~kg} \mathrm{ha}^{-1}$ along with Zinc at $25 \mathrm{~kg} \mathrm{ha}^{-1}$ as basal and foliar application of Boron at $0.3 \%$ recorded more in No. of cobs plant ${ }^{-1}$ (6.67), No. of grains cob ${ }^{-1}$ (304) and Test weight $(22.39 \mathrm{~g})$. Adequate supply of nitrogen is decisive for the activity of enzymes responsible for the number of starch granules in developing kernals (Cazetta et al., 1999). Potarzycki et al., (2015) ${ }^{[21]}$ observed that the zinc application to maize is a factor affecting positively its yielding potential. The yield forming effect of this nutrient prevailed in early 
stages of maize growth, resulting in a higher number of grains per cob.

Also, the same treatment recorded significantly maximum Grain yield (7.90 t ha $\left.\mathrm{t}^{-1}\right)$, Stover yield $\left(9.65 \mathrm{t} \mathrm{ha}^{-1}\right)$ and Harvest Index $(45.01 \%)$ (Table 1). Tahir et al., (2012) ${ }^{[29]}$ observed that the improvement in grain and biological yield of maize is mainly attributed to complementary role of boron in the reproduction and vegetative stage of plans. The present findings are well in agreement with that of Ceyhan et al. (2008) ${ }^{[5]}$, Blamey et al. (1997) ${ }^{[4]}$ and Schon and Blevins (1990) ${ }^{[25]}$. Shanti et al., (1997) ${ }^{[26]}$ reported that the result emphasizes the importance of adequate $\mathrm{N}$ supply tor the crop tor obtaining large-size cobs having more grains, with heavier and bold seeds that contribute to higher harvest indices and in turn higher grain yield.

\section{Economics}

Significantly the highest gross returns ₹ $1,12,775$ and net returns ₹77,290 with highest benefit: cost ratio 2.17 was recorded in the treatment with Nitrogen at $150 \mathrm{~kg} \mathrm{ha}^{-1}$, Phosphorus at $75 \mathrm{~kg} \mathrm{ha}^{-1}$, Potassium at $60 \mathrm{~kg} \mathrm{ha}^{-1}$ along with Zinc at $25 \mathrm{~kg} \mathrm{ha}^{-1}$ as basal and foliar application of Boron at $0.3 \%$.

Based on the experiment it can be concluded that the Maize variety "Pioneer 3401" recorded the highest yield and profits with Nitrogen at $150 \mathrm{~kg} \mathrm{ha}^{-1}$, Phosphorus at $75 \mathrm{~kg} \mathrm{ha}^{-1}$, Potassium at $60 \mathrm{~kg} \mathrm{ha}^{-1}$ along with Zinc at $25 \mathrm{~kg} \mathrm{ha}^{-1}$ as basal and Boron at $0.3 \%$ as foliar spray.

\section{References}

1. Amin. Effect of different nitrogen sources on growth, yield and quality of fodder maize (Zea mays L.). Journal of the Saudi Society of Agricultural Sciences. 2011; 10:17-23.

2. Arya KC, Singh SN. Productivity of Maize (Zea mays L.) as influenced by different levels of Phosphorus, Zinc and irrigation. Indian Journal of Agricultural Sciences. 2001; 71(1):57-59.

3. Baloch QB, Chachar QI, Tareen MN. Effect of foliar application of macro and micro nutrients on production of green chillies (Capsicum annuum L.). Journal of Agricultural Science and Technology. 2008; 4:177-184.

4. Blamey FPC, Zollinger RK, Schneiter AA. Sunflower production and culture; In: Sunflower Science and Technology. A.A. Schneiter (ed), Agronomy Monograph 35, ASA, CSSA and SSSA Madison, WI, USA, 1997, 595-670.

5. Ceyhan E, Onder M, Ozturk O, Harmankaya M, Hamurcu M, Gezgin S. Effects of application boron on yields, yield component and oil content of sunflower in boron-deficient calcareous soils. African Journal of Biotechnology. 2008; 7:2854-2861.

6. Erenoglu B, Nikolic M, Römhold V, Cakmak I. Uptake and transport of foliar applied zinc $(65 \mathrm{Zn})$ in bread and durum wheat cultivars differing in zinc efficiency. Plant and Soil. 2002; 241:251-257.

7. Fageria NK, Baligar VC, Jones CA. Growth and mineral nutrition of field crops. Marcel Dekker, New York, 1991.

8. Gasim SH. Effect of nitrogen, phosphorus and seed rate on growth, yield and quality of forage maize (Zea mays L.). M.Sc. Thesis, Faculty of Agric., Univ. of Khartoum, 2001.

9. Grzebisz W, Wrońska M, Diatta JB, Dullin P. Effect of zinc foliar application at early stages of maize growth on patterns of nutrients and dry matter accumulation by the canopy. Part I. Zinc uptake patterns and its redistribution among maize organs. Journal of Elementology. 2008; 13:17-28.

10. Gul S, Khan MH, Khanday BA, Nabi S. Effect of Sowing Methods and NPK Levels on Growth and Yield of Rainfed Maize (Zea mays L.) Hindawi Publishing Corporation Scientifica Article ID 198575, 2015, 6.

11. Shanti KVP, Rao MR, Reddy MS, Sarma RS. Response of maize (Zea mays) hybrid and composite to different levels of nitrogen. The Indian Journal of Agricultural Sciences. 1997; 67:424-425.

12. Koul GG. Effect of sowing methods, nitrogen levels and seedrates on yield and quality of fodder maize (Zea mays L.). M.Sc. Thesis, Univ. of Khartoum, Faculty of Agric, 1997.

13. Kumar R, Srinivas K, Sivaramane N. Assessment of the maize situation, outlook and investment opportunities in India. National Academy of Agricultural Research Management, 2013.

14. Lošák T, Hlušek J, Martinec J, Jandák J, Szostková M, Filipcik $\mathrm{R}$ et al. Nitrogen fertilization does not affect micronutrient uptake in grain maize (Zea mays L.). Acta Agriculturae Scandinavistica, Section B - Soil and Plant Science. 2011; 61:543-550.

15. Haque MM, Hamid A, Bhuiyan NI. Nutrient uptake and productivity as affected by nitrogen and potassium application levels $\mathrm{N}$ maize/sweet potato intercropping system. Korean Journal of Crop Science. 2001; 46(1):1-5.

16. Maňásek J, Lošák $T$, Prokeš $K$, Hlušek $J$, Vítězová $M$, Škarpa $\mathrm{P}$ et al. Effect of nitrogen and potassium fertilization on micronutrient content in grain maize (Zea mays L.). Acta Universitatis Agriculturaeet Silviculturae Mendelianae Brunensis. 2013; 61:123-128.

17. Marten JM, Westermann DT. Fertilizer applications for correcting micronutrient deficiencies. In: Mortvedt JJ, Cox FR, Shuman LM, Welch RM (eds) Micronutrients in agriculture, SSSA Book Series No. 4. Soil Science Society of America, Wisconsin, 1991, 549-592.

18. Martin JH, Leonard WH, Stamp DL. Principles of field crop production, 3rd edn. Macmillan, New York, 1976.

19. Mazher AM, Zaghloul SM, Yassen AA. Impact of boron fertilizer on growth and chemical constituents of Taxodium distichum grown under water regime. World Journal of Agricultural Sciences. 2006; 2:412-420.

20. Brady NC. The Nature and Properties of Soils, Macmillan Publishing Company, New York, NY, USA, 1984.

21. Potarzycki J, Przygocka-Cyna K, Grzebisz W, Szczepaniak W. Effect of zinc application timing on yield formation by two types of maize cultivars. Plant Soil Environ. 2015; 61(10):468-474.

22. Rashid A, Ryan J. Micronutrient constraints to crop production in soils with Mediterranean-type characteristics: A review. Journal of Plant Nutrition. 2004; 27:959-975.

23. Saigusa M, Kasagaya Y, Watarable, Shibuya K. Ecology of apple of pru (Nicandra physalodes L.). Press and Velvet Leaf (Abutilon avicennae Garth), 1999.

24. Savithri P, Perumal R, Nagarajan R. Soil and crop management technologies for enhancing rice production under micronutrient constraints. Nutrient Cycling in Agroeco systems. 1999; 53:83-92.

25. Schon M, Blevins D. Foliar boron applications increase the final number of branches and pods on branches of 
field-grown soybeans. Plant Physiology, 1990; 92:602605.

26. Shanti K, Rao VP, Reddy MR, Reddy MS, Sarma PS. Response of maize (Zen mays) hybrid and composite to different levels of nitrogen. Indian Journal of Agricultural Sciences. 1997; 67(9):424-425.

27. Sharma RK. Response of maize to nitrogen fertilization. Madras Agricultural Journal. 1973; 60:399-440.

28. Shorrocks VM, Blaza AJ. The boron nutrition of maize. Field Crop. 1973; 25:25-27.

29. Tahir M, Ali A, Khalid F, Naeem M, Fiaz N, Waseem M. Effect of Foliar Applied Boron Application on Growth, Yield and Quality of Maize (Zea mays L.). Pakistan Journal of Scientific and Industrial Research Ser. B: boil. Sci. 2012; 55(3):117-121.

30. Turkhede BB, Rajendra P. Effect of rates and timing of nitrogen application on hybrid sorghum. Indian Journal of Agronomy. 1978; 23(2):113-126.

31. Vaughan AKF. The relation between the concentration of boron in the reproductive and vegetative organ of maize plants and their development. Rhod J Agric Res. 1977; 15:163-170.

32. Woodruff JR, Moore FW, Musen HL. Potassium, boron, nitrogen and lime effects on corn yield and ear leaf nutrients concentration. Agronomy Journal. 1987; 79:520-524. 